\title{
Effect of Minor Alloying Elements on the Corrosion Behavior of Fe40Al in NaCl-KCl Molten Salts
}

\author{
G. Salinas, ${ }^{1}$ J. G. Gonzalez-Rodriguez, ${ }^{1} \mathrm{~J}^{\text {Porcayo-Calderon, }}{ }^{2}$ \\ V. M. Salinas-Bravo, ${ }^{2}$ and M. A. Espinoza-Medina ${ }^{3}$ \\ ${ }^{1}$ CIICAP, Universidad Autónoma del Estado de Morelos, Avendia Universidad 1001, Colonia Chamilpa, \\ 62209 Cuernavaca, MOR, Mexico \\ ${ }^{2}$ IIE, Gerencia de Procesos Térmicos, Avenida Reforma 120, 62490 Temixco, MOR, Mexico \\ ${ }^{3}$ Facultad de Ingeniera Mecanica, Universidad Michoacana de San Nicolás de Hidalgo, 58000 Morelia, MICH, Mexico \\ Correspondence should be addressed to J. G. Gonzalez-Rodriguez, ggonzalez@uaem.mx
}

Received 2 February 2012; Accepted 18 May 2012

Academic Editor: Vesna Mišković-Stanković

Copyright ( 2012 G. Salinas et al. This is an open access article distributed under the Creative Commons Attribution License, which permits unrestricted use, distribution, and reproduction in any medium, provided the original work is properly cited.

The hot corrosion behavior of $\mathrm{Fe} 40 \mathrm{Al}$ intermetallic alloyed with $\mathrm{Ag}, \mathrm{Cu}, \mathrm{Li}$, and $\mathrm{Ni}(1-5 \mathrm{at} . \%)$ in $\mathrm{NaCl}-\mathrm{KCl}(1: 1 \mathrm{M})$ at $670^{\circ} \mathrm{C}$, typical of waste gasification environments, has been evaluated by using polarization curves and weight loss techniques and compared with a 304-type stainless steel. Both gravimetric and electrochemical techniques showed that all different Fe40Al-base alloys have a much higher corrosion resistance than that for stainless steel. Among the different Fe40Al-based alloys, the corrosion rate was very similar among each other, but it was evident that the addition of Li decreased their corrosion rate whereas all the other elements increased it. Results have been explained in terms of the formation and stability of an external, protective $\mathrm{Al}_{2} \mathrm{O}_{3}$ layer.

\section{Introduction}

Sodium and potassium impurities present in the form of chloride or sulfates are very corrosive constituents under certain combustion conditions such as waste incinerators and biomass-fired boilers $[1,2]$. Early failure of the thermal components frequently occurs due to the complex reactions between the metallic materials and the hostile combustion environment. Problems with process equipment resulting from fireside corrosion have been frequently encountered in incinerators. The major problem is the complex nature of the feed (waste) as well as corrosive impurities which form low-melting point compounds with heavy and alkali metal chlorides which prevent the formation of protective oxide scales and then causes an accelerated degradation of metallic elements [1]. In particular, under reducing conditions such as those typical of the operation of waste gasification plants or even under localized reducing conditions, which frequently arise in the case of incorrect operation of waste incineration systems, it is difficult to form protective oxide scales such as $\mathrm{Cr}_{2} \mathrm{O}_{3}, \mathrm{SiO}_{2}$, and $\mathrm{Al}_{2} \mathrm{O}_{3}$ on the surface of structural materials. Thus, the corrosion attack can be further enhanced under reducing atmospheres in the presence of salt deposits [2].

The effect of individual $\mathrm{KCl}, \mathrm{NaCl}$, and their mixtures with heavy metal chlorides or sulfates on the corrosion behavior of a series of alloy systems has been studied in detail so far [2-9]. It is generally realized that $\mathrm{Cr}$ is not as effective element for corrosion resistance of Fe-based and Ni-based alloys due to chloride attack. In contrast, alumina- $\left(\mathrm{Al}_{2} \mathrm{O}_{3}-\right)$ forming alloys exhibit promising candidate materials considering the better high temperature resistance of alumina over chromia and their properties such as lower cost, low density, high strength, and good wear resistance [10-13].

In order to obtain more information on the corrosion mechanisms taking place, electrochemical techniques are more appropriated than gravimetric methods. Since a molten salt acts as an electrolyte, electrochemical techniques such as potentiodynamic polarization curves and linear polarization resistance (LPR) measurements can be used just 


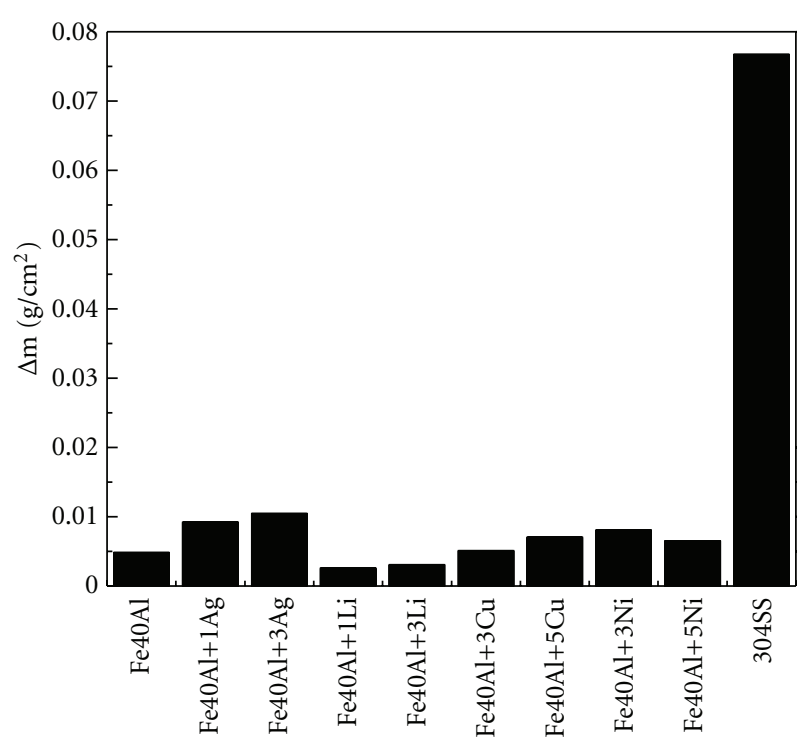

Figure 1: Effect of $\mathrm{Ag}, \mathrm{Li}, \mathrm{Cu}$, and $\mathrm{Ni}$ on the weight loss for $\mathrm{Fe} 40 \mathrm{Al}$ alloy in $\mathrm{NaCl}-\mathrm{KCl}\left(1: 1\right.$ molar ratio) deposit in static air at $670^{\circ} \mathrm{C}$.

like Ducati et al. [14] showed in one of the earliest works on this topic. Zeng et al. used electrochemical impedance spectroscopy (EIS) studies for the corrosion of two-phase $\mathrm{Cu}-15 \mathrm{Al}$ alloy in the eutectic $(\mathrm{Li}, \mathrm{K})_{2} \mathrm{CO}_{3}$ at $650^{\circ} \mathrm{C}[15]$ and for $\mathrm{Ni}_{3} \mathrm{Al}$ alloy in $(\mathrm{Li}, \mathrm{Na}, \mathrm{K})_{2} \mathrm{SO}_{4}$ at $650^{\circ} \mathrm{C}$ [16]. They found that the complex plane of the electrochemical impedance suggested that the fast corrosion rate of these alloys was due to the formation of a nonprotective oxide and that the corrosion process was controlled by the diffusion of oxidants. Shirvani et al. [17] used polarization curves to study the corrosion performance of the slurry Si-modified aluminide coating on the nickel base super alloy In-738LC exposed to $\mathrm{Na}_{2} \mathrm{SO}_{4}-20 \mathrm{wt} . \% \mathrm{NaCl}$ melt at $750^{\circ} \mathrm{C}$. Zhu et al. [18] used Tafel extrapolation, linear polarization resistance, chronopotentiometry, and EIS to determine corrosion rates of iron and iron-based alloys in molten carbonate melts for both cathode and anode in molten carbonate fuel cell (MCFC) environments. Cuevas-Arteaga and coworkers [1921] have successfully used electrochemical techniques to study the corrosion of materials used in sulfate+vanadate environments and obtained information about both the type and mechanisms of corrosion on these environments. Thus, this work deals with an electrochemical study of the effect of adding alloying element such as $\mathrm{Cu}, \mathrm{Li}, \mathrm{Ni}$, and $\mathrm{Ag}$ to a Fe40Al intermetallic alloy corroded in $\mathrm{NaCl}-\mathrm{KCl}(1: 1 \mathrm{M})$ at $670^{\circ} \mathrm{C}$. For comparison, traditional weight loss experiments have been performed too.

\section{Experimental Procedure}

Cast ingots of binary $\mathrm{Fe}-40$ at.\% $\mathrm{Al}$ and ternary Fe40Al$\mathrm{X}(\mathrm{X}=1$ and 3 at.\% for $\mathrm{Cr}$ or $\mathrm{Li}, 3$ and 5 at.\% for $\mathrm{Ni}$ or Ag) alloys were fabricated using a high-frequency vacuum induction furnace. Chemical elements of high purity (99.9\%) were placed in an alumina crucible placed inside a graphite crucible in order to be induction melted under

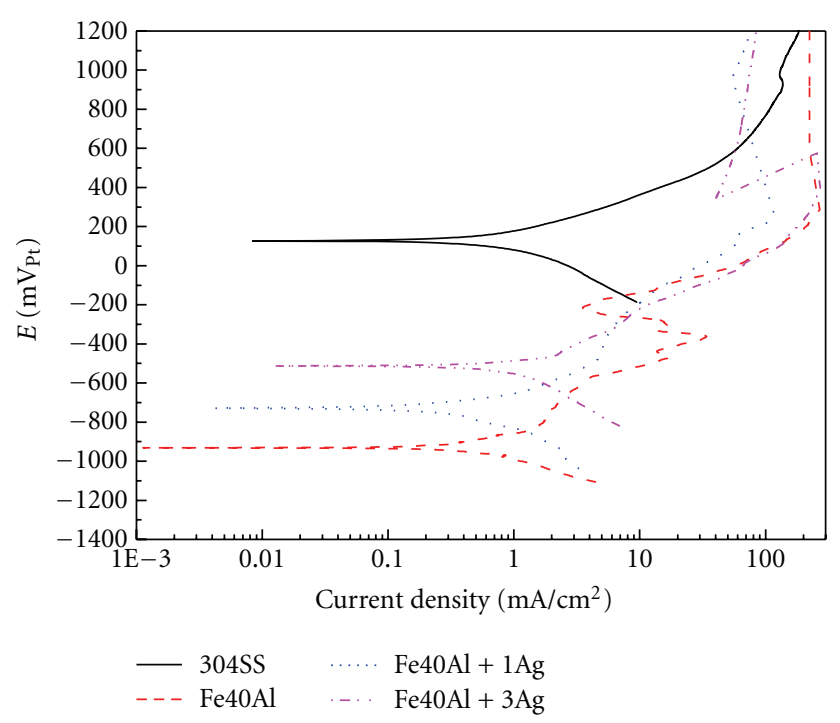

FIGURE 2: Effect of Ag on the polarization curve for Fe40Al alloy in $\mathrm{NaCl}-\mathrm{KCl}\left(1: 1\right.$ molar ratio) salt in static air at $670^{\circ} \mathrm{C}$.

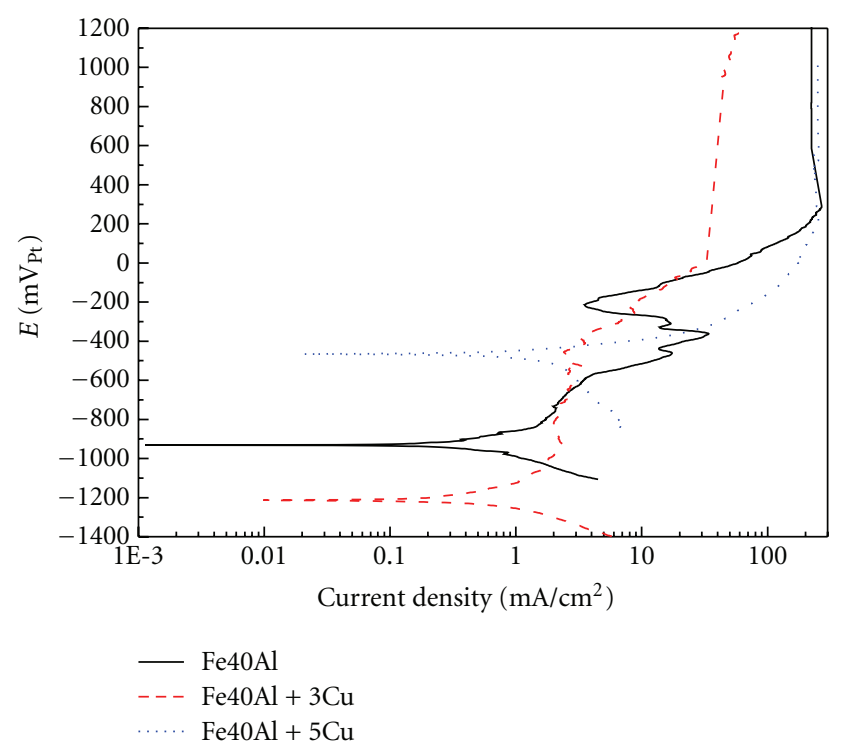

FIGURE 3: Effect of $\mathrm{Cu}$ on the polarization curve for Fe40Al alloy in $\mathrm{NaCl}-\mathrm{KCl}\left(1: 1\right.$ molar ratio) salt in static air at $670^{\circ} \mathrm{C}$.

vacuum. The molten Fe-40Al, Fe40Al-X alloys were poured into a rectangular cooper mould. The produced ingots were cut by a diamond wheel cutter in small rectangular parallelepiped pieces of surface area ranging from 1.5 to $2.5 \mathrm{~cm}^{2}$. Potentiodynamic polarization curves and weight loss measurements were used. Details of the experimental setup for the electrochemical cell used in this work are given elsewhere [22]. The body of the cell was a $15 \mathrm{~mL}$ silica crucible. The most important elements were a reference and auxiliary electrodes, made of a $0.5 \mathrm{~mm}$ diameter platinum $(\mathrm{Pt})$ wire inside a mullite tube and filled with commercial refractory, ceramic cement. The amount of salt in each run was $0.5 \mathrm{~g}$ for an exposed area of $1.0 \mathrm{~cm}^{2}$ under static 


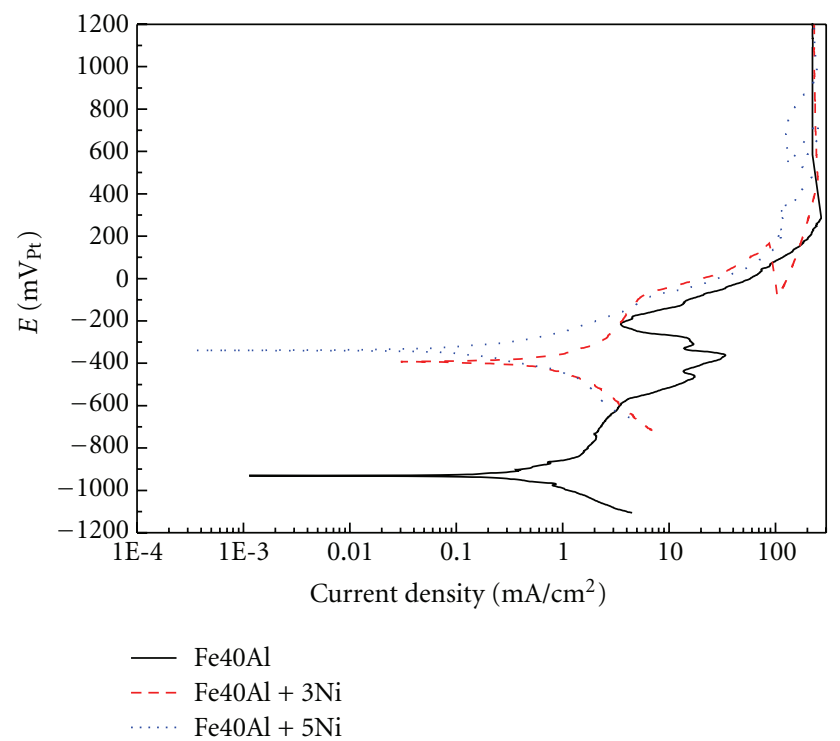

FIgURE 4: Effect of Ni on the polarization curve for Fe40Al alloy in $\mathrm{NaCl}-\mathrm{KCl}\left(1: 1\right.$ molar ratio) salt in static air at $670^{\circ} \mathrm{C}$.

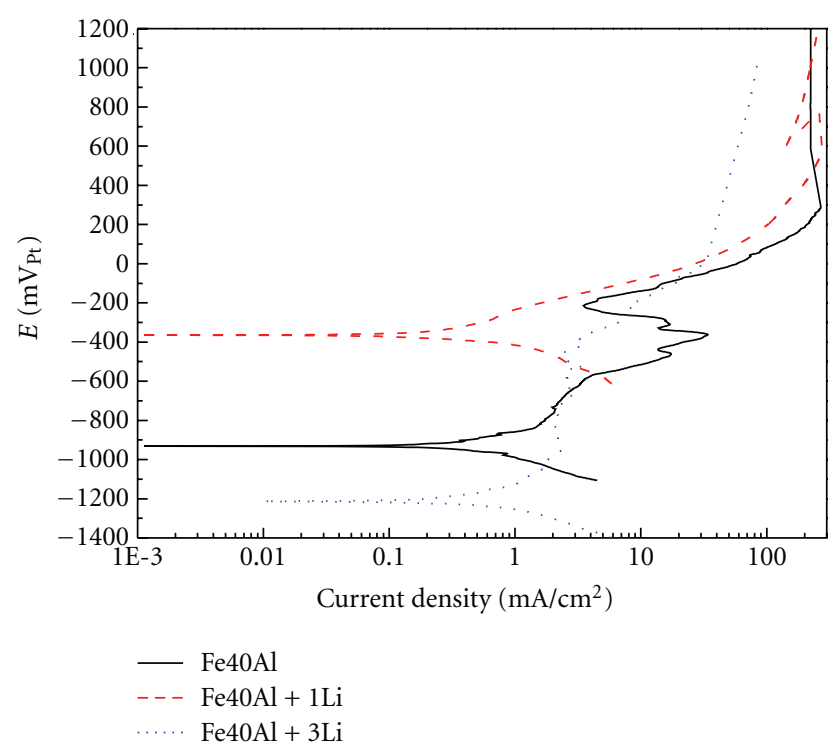

FIGURE 5: Effect of Li on the polarization curve for Fe40Al alloy in $\mathrm{NaCl}-\mathrm{KCl}\left(1: 1\right.$ molar ratio) salt in static air at $670^{\circ} \mathrm{C}$.

conditions. The electrical contact was made by welding an 80 wt.\% Cr-20 Ni wire to the specimen. Polarization curves were obtained by polarizing the specimens from -500 to $+1500 \mathrm{mV}_{\mathrm{Pt}}$ with respect to the free corrosion potential value, $E_{\text {corr }}$, at a scanning rate of $1.0 \mathrm{mV} / \mathrm{s}$. Corrosion current density values, $I_{\text {corr }}$, were calculated by using the Tafel extrapolation method, which is valid for the sweep rates used here according to [21] and taking an extrapolation zone of $\pm 250 \mathrm{mV}$ around the $E_{\text {corr }}$ value once it was stable. The working salt consisted of $500 \mathrm{mg} / \mathrm{cm}^{2}$ of an eutectic mixture of $\mathrm{NaCl}-\mathrm{KCl}, 1: 1 \mathrm{M}$, analytical grade for each test. The testing temperature was $670^{\circ} \mathrm{C}$ in static air condition.

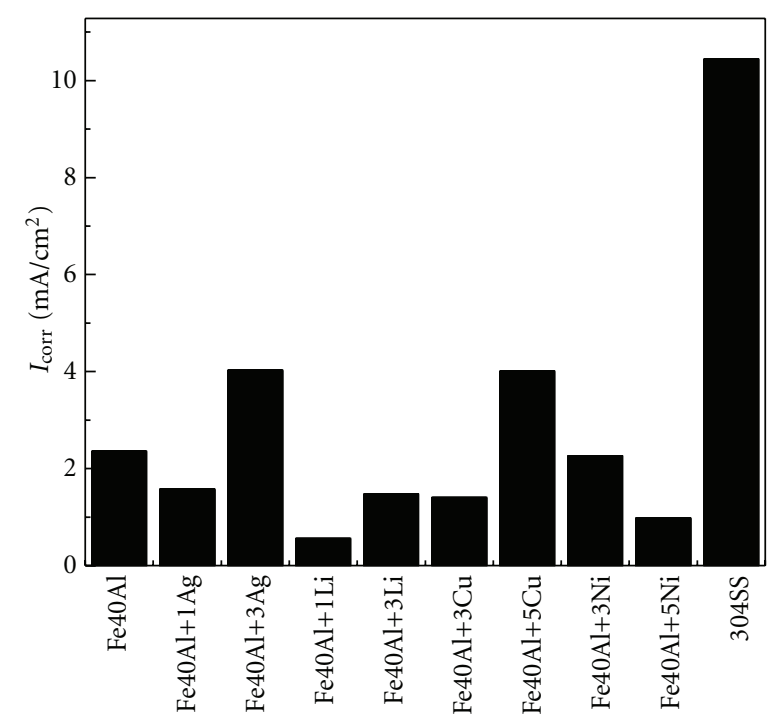

FIGURE 6: Effect of $\mathrm{Ag}, \mathrm{Li}, \mathrm{Cu}$, and $\mathrm{Ni}$ on the $I_{\text {corr }}$ values for Fe40Al alloy in $\mathrm{NaCl}-\mathrm{KCl}\left(1: 1\right.$ molar ratio) deposit in static air at $670^{\circ} \mathrm{C}$.

Prior the tests, the specimen surfaces were prepared by the standard technique of grinding with $\mathrm{SiC}$ from 240 to 600 grit emery paper, washed with water, and degreased with acetone. Weight loss tests were carried out in electric furnaces in a static air during 100 hours. All materials were machined into specimens with dimensions of about $10 \mathrm{~mm} \times 15 \mathrm{~mm}$ $\times 1.5 \mathrm{~mm}$, then grounded to 600 grade emery paper, and cleaned in a supersonic bath of acetone. After the corrosion tests, the corrosion rate was measured as weight loss. Three specimens of each condition test were decaled and chemically cleaned according to ASTM G1 81 standard. For comparison, the same tests were done with a 304-type stainless steel. One of each heat was mounted in bakelite in cross-section and polished to analyze the subsurface corrosive attack using a scanning electron microscopy (SEM) aided with energy dispersive spectroscopy (EDX) to carry out microchemical analysis.

\section{Results and Discussion}

Figure 1 shows that the mass loss for the different alloys alters being exposed to an eutectic $\mathrm{NaCl}-\mathrm{KCl}$ mixture at $670^{\circ} \mathrm{C}$ during 100 hours. It can be seen that 304-type stainless steel suffered the greatest corrosion rate, more than one order of magnitude higher than that for all the Fe40-based alloys. Li et al. [2] obtained very similar results with an Fe45Al alloy in $\mathrm{NaCl}-\mathrm{KCl}$ mixture at $670^{\circ} \mathrm{C}$ during 100 hours. Among the different Fe40Al-based alloys, the addition of either 1 or $3 \%$ $\mathrm{Li}$ decreased the corrosion rate of unalloyed Fe40Al alloy, whereas the addition of Ag, Ag or Ni increased it; however, this difference is marginal.

The effect of 1 and 3\% Ag on the polarization curves for Fe40Ag base alloy, together with that one for 304type stainless steel, is shown on Figure 2. It can be seen that unalloyed Fe40Al-based alloy displays an active-passive behavior, with an $E_{\text {corr }}$ value close to $-927 \mathrm{mV}$ and an $I_{\text {corr }}$ 


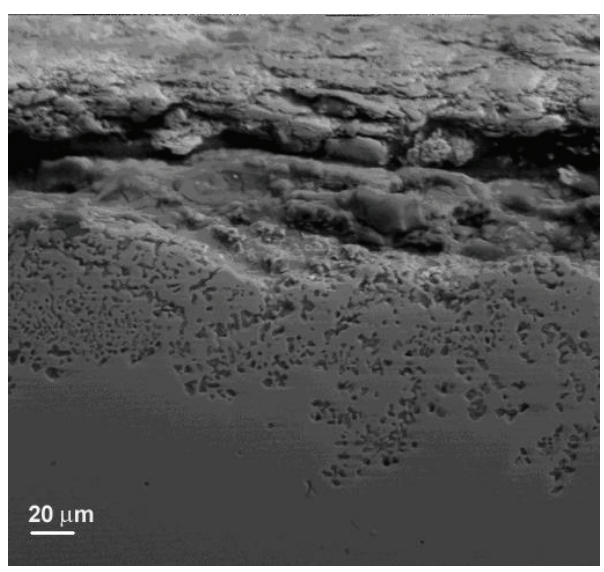

(a)

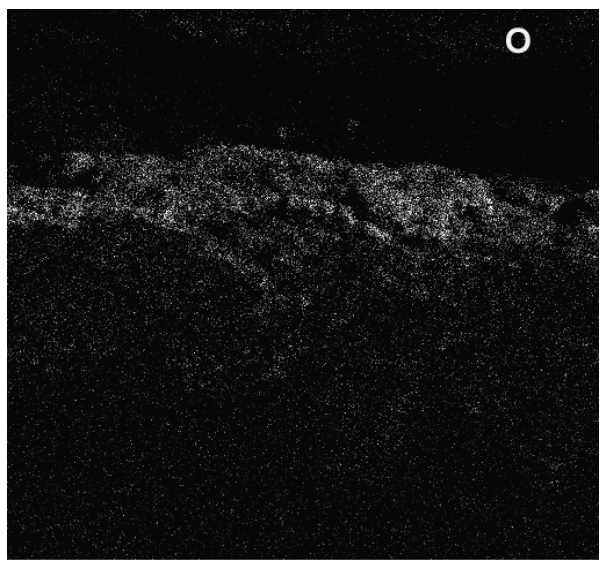

(c)

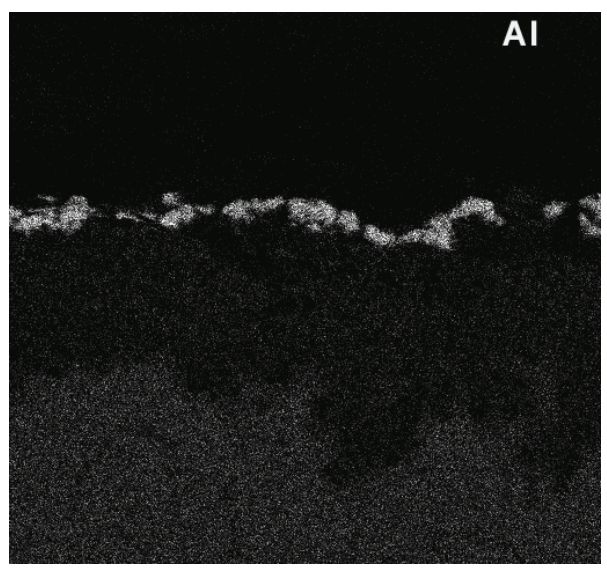

(b)

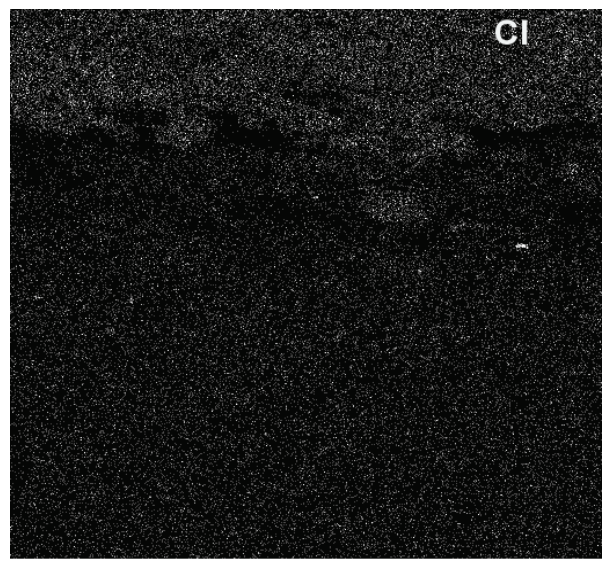

(d)

Figure 7: Micrograph of $\mathrm{Fe} 40 \mathrm{Al}$ alloy corroded in $\mathrm{NaCl}-\mathrm{KCl}$ at $670^{\circ} \mathrm{C}$ together with the $\mathrm{X}$-ray mappings of $\mathrm{Al}, \mathrm{O}$, and $\mathrm{Cl}$.

value of $0.15 \mathrm{~mA} / \mathrm{cm}^{2}$. As the applied potential is more anodic, the anodic current density value increases until it reaches a more or less constant value, that is, a passive region, between -800 and $-600 \mathrm{mV}$, where a sudden increase in the current density value appears. Some anodic peaks are observed at -500 and $-400 \mathrm{mV}$, respectively. A second, narrow passive region can be observed around $-200 \mathrm{mV}$, after which the anodic current density increases once again until it reaches an anodic limit current density. This might be due to the presence of an external layer which acts as a barrier against the ingress of the aggressive species. When $\mathrm{Ag}$ was added into the alloy, the $E_{\text {corr }}$ value is made more anodic and the $I_{\text {corr }}$ value is increased. The presence of a passive region in the Ag-containing alloys is not very clear; however, for both alloys, around $-450 \mathrm{mV}$ the anodic current density value showed a more or less constant value, although this was not so evident for the alloy containing 3\% Ag. The presence of an anodic limit current density, lower than that observed for the Fe40Al base alloy, is observed in both cases at a potential value close to $200 \mathrm{mV}$. The corrosion current density value for 304-type stainless steel was higher than that for the three Fe40Al-based alloys for at least one order of magnitude, and there was no evidence of a passive region.
According to the mass loss data (Figure 1) 304-type stainless steel had the highest corrosion rate too.

The addition of $3 \% \mathrm{Cu}$ did not affect very much the $I_{\text {corr }}$ value as the addition of $5 \% \mathrm{Cu}$ did, as can be seen on Figure 3. The free corrosion potential became more active with the addition of $3 \% \mathrm{Cu}$, but it became much nobler when $5 \% \mathrm{Cu}$ was added. The passive region in the alloy containing $3 \% \mathrm{Cu}$ was much wider and more stable than that shown by the unalloyed base alloy, starting around $-1100 \mathrm{mV}$ and finishing around $-300 \mathrm{mV}$, where a breakdown potential is obtained. There was no evidence of apassive region for the alloy containing $5 \% \mathrm{Cu}$, only anodic dissolution, with the highest anodic current density value. Similarly, the addition of either 3 or $5 \% \mathrm{Ni}$ shifted the $E_{\text {corr }}$ value towards the noble direction, whereas the $I_{\text {corr }}$ value was slightly decreased only with the addition of $5 \% \mathrm{Ni}$ (Figure 4 ). The presence of a passive region was found only with the addition of $3 \% \mathrm{Ni}$ between -300 and $0 \mathrm{mV}$, where the breakdown potential was reached. After this point, an anodic limit current density value is observed in both cases, with a value slightly lower than that found for unalloyed Fe40Al-base alloy.

Finally, when Li was added (Figure 5), the $E_{\text {corr }}$ value became nobler with the addition of $1 \%$ but more active with 


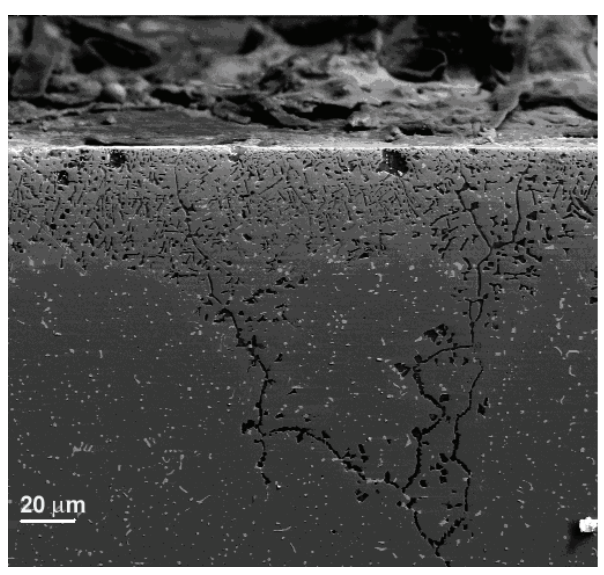

(a)

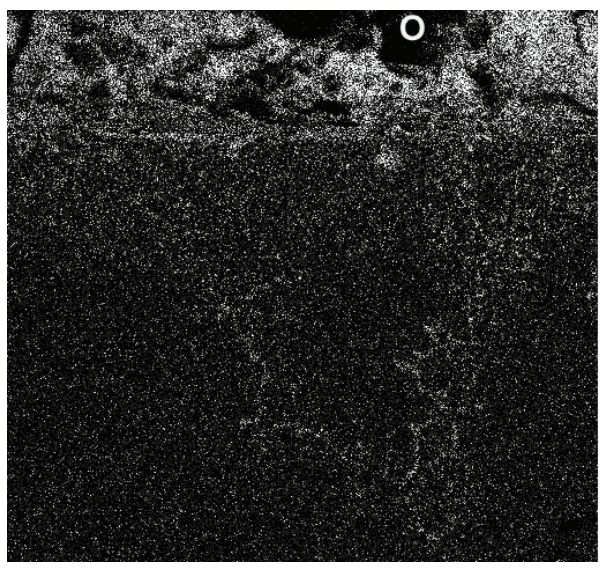

(c)

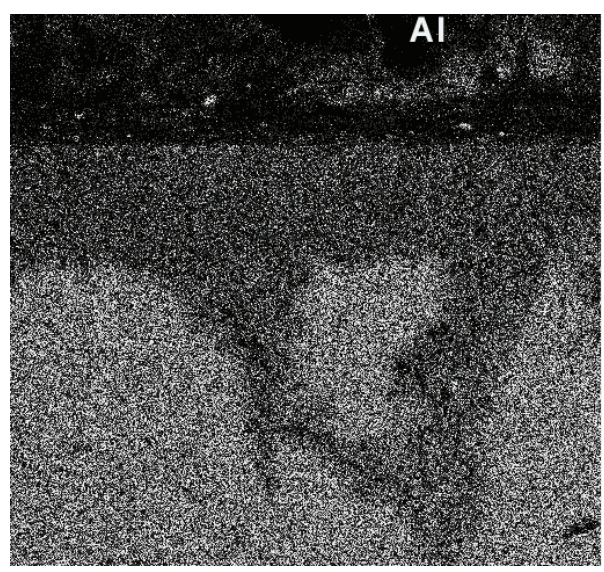

(b)

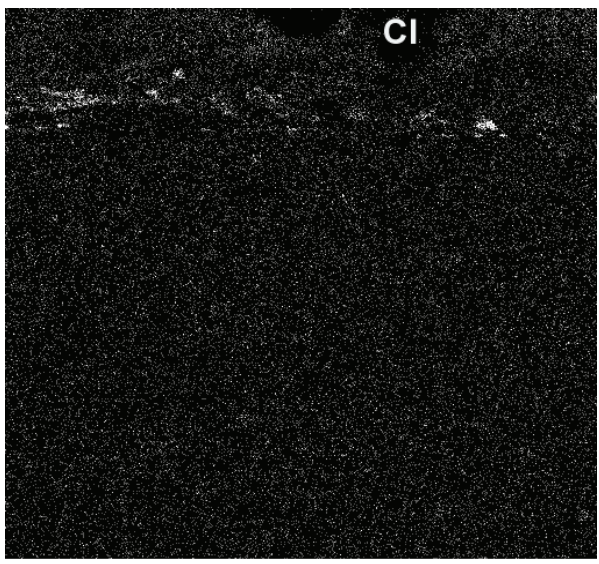

(d)

Figure 8: Micrograph of $\mathrm{Fe} 40 \mathrm{Al}+3 \mathrm{Ag}$ alloy corroded in $\mathrm{NaCl}-\mathrm{KCl}$ at $670^{\circ} \mathrm{C}$ together with the $\mathrm{X}$-ray mappings of $\mathrm{Al}$, $\mathrm{O}$, and $\mathrm{Cl}$.

3\% Li. In addition, the corrosion rate, expressed in terms of the corrosion current density values, was decreased in both cases, just as evidenced by the weight loss results in Figure 1 . A much wider and stable passive region than that found on the unalloyed $\mathrm{Fe} 40 \mathrm{Al}$ based-alloy is found between -1000 and $-300 \mathrm{mV}$. Unlike this, no passive region can be seen with the addition of $1 \% \mathrm{Li}$, but only anodic dissolution until an anodic limit current density is reached. Thus, it can be seen that different alloying elements have a different effect on the electrochemical behavior of $\mathrm{Fe} 40 \mathrm{Al}$ alloy in molten $\mathrm{NaCl}-$ $\mathrm{KCl}$. Table 1 gives a summary of the different electrochemical parameters obtained from the polarization curves. Figure 6 gives the corrosion current density values, $I_{\text {corr }}$, for all the Fe40Al-based alloys, where it can be seen that the highest value corresponds to the 304-type stainless steel, whereas the lowest value corresponds to the Li-containing alloys. Similar results were obtained with the weight loss test (Figure 1), thus, both gravimetric and electrochemical techniques gave similar results: all the different Fe40Al-based alloys have a better corrosion performance than that for 304-type stainless steel in the $\mathrm{NaCl}-\mathrm{KCl}$ mixture at $670^{\circ} \mathrm{C}$.

Figure 7 shows a micrograph of corroded unalloyed Fe40Al-based alloy together with the X-ray mappings of Al, $\mathrm{O}$, and $\mathrm{Cl}$, where it can be seen the presence of both $\mathrm{Al}$
TABLE 1: Electrochemical parameters obtained from polarization curves.

\begin{tabular}{lcccc}
\hline Alloy & $\beta_{a}(\mathrm{mV} / \mathrm{dec})$ & $\beta_{c}(\mathrm{mV} / \mathrm{dec})$ & $I_{\text {corr }}\left(\mathrm{mA} / \mathrm{cm}^{2}\right)$ & $E_{\text {corr }}(\mathrm{mV})$ \\
\hline FeAl-base & 311 & 223 & 1.5 & -927 \\
FeAl-1Ag & 293 & 398 & 2.3 & -730 \\
FeAl-3Ag & 269 & 432 & 4.0 & -510 \\
FeAl-1Li & 159 & 65 & 0.5 & -363 \\
FeAl-3Li & 346 & 134 & 1.4 & -1212 \\
FeAl-3Cu & 169 & 180 & 1.4 & -1212 \\
FeAl-5Cu & 78 & 191 & 4 & -460 \\
FeAl-3Ni & 159 & 207 & 2.2 & -395 \\
FeAl-5Ni & 177 & 222 & 0.9 & -340 \\
304SS & 243 & 311 & 10.4 & 125 \\
\hline
\end{tabular}

and $\mathrm{O}$, maybe representing the formation of what seems to be a protective $\mathrm{Al}_{2} \mathrm{O}_{3}$ oxide, which is the responsible for the passive behavior observed in the polarization curve for this alloy (Figure 2); the absence of $\mathrm{Al}$ and $\mathrm{O}$ in some points indicates that the external $\mathrm{Al}_{2} \mathrm{O}_{3}$ oxide is porous and it has been dissolved by aggressive molten salt. $\mathrm{Li}$ et al. [2], corroding an $\mathrm{Fe} 45 \mathrm{Al}$ alloy in $\mathrm{NaCl}-\mathrm{KCl}$ salt at 


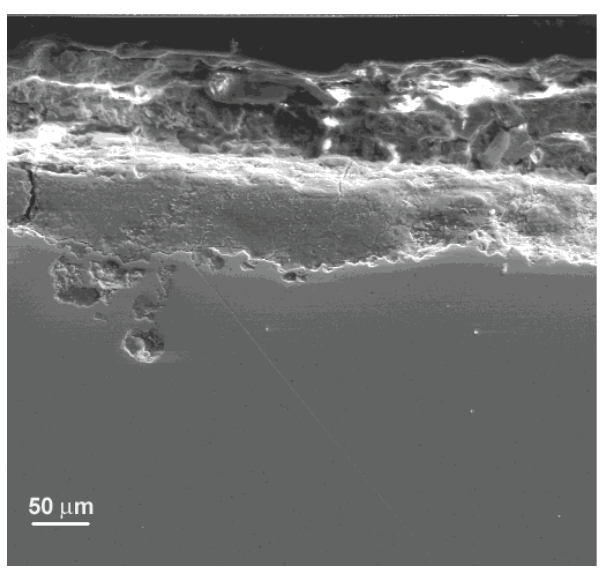

(a)

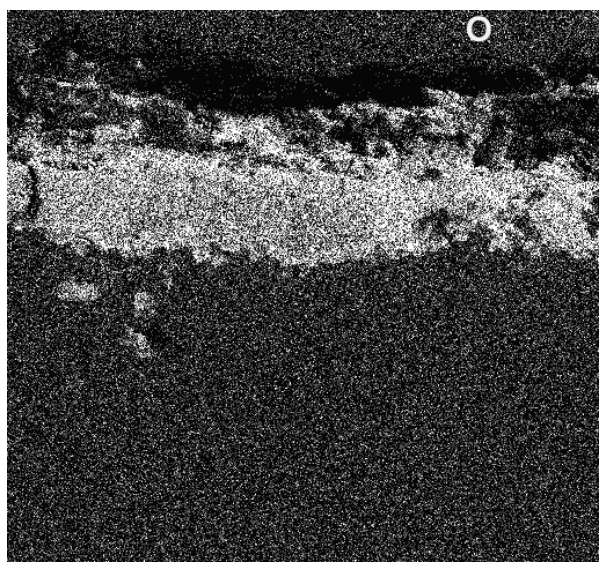

(c)

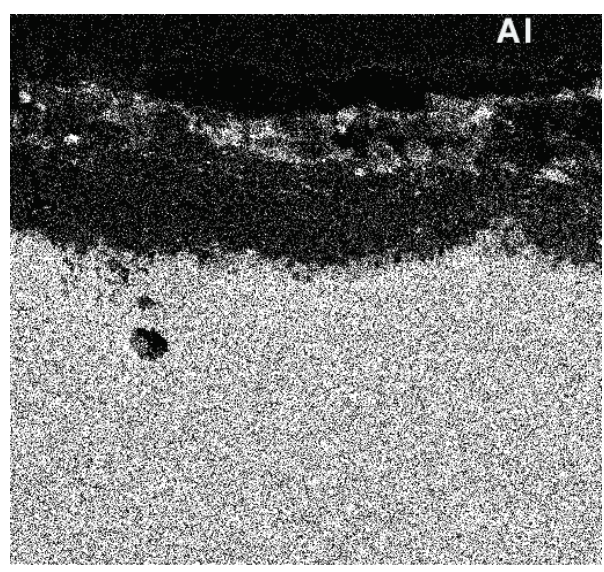

(b)

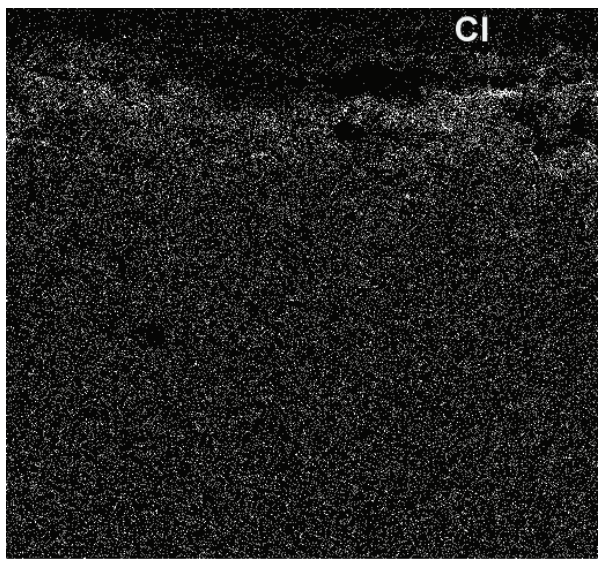

(d)

Figure 9: Micrograph of Fe40Al + 3Li alloy corroded in $\mathrm{NaCl}-\mathrm{KCl}$ at $670^{\circ} \mathrm{C}$ together with the $\mathrm{X}$-ray mappings of $\mathrm{Al}$, $\mathrm{O}$, and $\mathrm{Cl}$.

$670^{\circ} \mathrm{C}$ during 48 hours, found $\mathrm{Al}_{2} \mathrm{O}_{3}$ as the main compound formed on the external layer. For the alloy containing $3 \mathrm{Ag}$, Figure 8, there is evidence of $\mathrm{Al}, \mathrm{O}$, and $\mathrm{Cl}$, indicating the formation of an external protective $\mathrm{Al}_{2} \mathrm{O}_{3}$ oxide dissolved by the $\mathrm{Cl}$-containing salt; however, there is evidence of internal oxidation along the grain boundaries. The formation of an external $\mathrm{Al}_{2} \mathrm{O}_{3}$ oxide is more evident for the alloy containing $3 \mathrm{Li}$ (Figure 9), where it can be seen that aggressive ions such as $\mathrm{Cl}^{-}$practically remain outside the protective $\mathrm{Al}_{2} \mathrm{O}_{3}$ oxide, but, eventually, the molten salt dissolves this oxide and dissolves the underlying alloy. Both chlorine and aluminum seem to form a compound on the external salt, which, according to $\mathrm{Li}$ et al. [2], could be liquid $\mathrm{AlCl}_{3}$, which melts at $192^{\circ} \mathrm{C}$. An Al-depleted and an O-rich zone can be observed in all alloys. These two alloys showed an activepassive behavior in their polarization curves (Figures 2 and 5 ), which is due to the presence of a very adherent, protective $\mathrm{Al}_{2} \mathrm{O}_{3}$ layer.

Thus, it can be seen that the corrosion protection of an alloy against salt melt attack depends on the chemical stability of both the kind of metal and their compounds such as oxides and chlorides. In fact, a breakdown of the protective oxide readily occurs by dissolution into the melt, and the degradation rate can be especially fast if the oxide has a high solubility in the melt. Since from a thermodynamic point of view, $\mathrm{Al}$ is the most reactive element among all the different investigated elements here; Al chloride or oxide forms preferentially over the other elements. At the melt-substrate interface, the oxygen potential is low while the chlorine potential is relatively high, and, consequently, liquid aluminum chloride forms there and transports outwards, leaving an aluminum depleted layer as observed in Figures 7-9. Near the melt-atmosphere interface, the transition from aluminum chloride to its oxide occurs, which onlyrelatively low oxygen pressure is needed because of the very stablenature of aluminum oxide. Therefore, the preferential removal of aluminum from the matrix is enhanced, basically in the form of highly volatile liquid chloride. This process seems to be beneficial to help establish a protective alumina, $\mathrm{Al}_{2} \mathrm{O}_{3}$, scale due to a fast aluminum supply. The role of the different alloying elements is to help to make more stable the alumina layer on top of the alloy and increase the alloy corrosion rate in the melt.

\section{Conclusions}

A study of the effect of alloying elements such as $\mathrm{Ag}, \mathrm{Li}, \mathrm{Cu}$, and $\mathrm{Ni}$ on the corrosion resistance of $\mathrm{Fe} 40 \mathrm{Al}$ intermetallic 
alloy beneath a $\mathrm{NaCl}-\mathrm{KCl}$ mixture in air at $670^{\circ} \mathrm{C}$ has been carried out by using both weight loss and potentiodynamic polarization curves. Both techniques have shown that the corrosion rate of the different Fe40Al-based alloys is much lower than that for 304-type stainless steel for nearly one order of magnitude. Addition of Li decreased the corrosion rate of unalloyed Fe40Al-base alloy, whereas the addition of $\mathrm{Ag}, \mathrm{Ni}$, or $\mathrm{Cu}$ increased it. However, the corrosion rate for the different Fe40Al-based alloys was within the same order of magnitude. Results have been explained in terms of the formation and stability of an external, protective alumina, $\mathrm{Al}_{2} \mathrm{O}_{3}$, layer.

\section{References}

[1] C. S. Ni, L. Y. Lu, C. L. Zeng, and Y. Niu, "Electrochemical impedance studies of the initial-stage corrosion of $310 \mathrm{~S}$ stainless steel beneath thin film of molten $(0.62 \mathrm{Li}, 0.38 \mathrm{~K})_{2} \mathrm{CO}_{3}$ at $650^{\circ}$ C," Corrosion Science, vol. 53, no. 3, pp. 1018-1024, 2011.

[2] Y. S. Li, M. Spiegel, and S. Shimada, "Corrosion behaviour of various model alloys with $\mathrm{NaCl}-\mathrm{KCl}$ coating," Materials Chemistry and Physics, vol. 93, no. 1, pp. 217-223, 2005.

[3] Nobuo Otsuka, "Effects of fuel impurities on the fireside corrosion of boiler tubes in advanced power generating systems - a thermodynamic calculation of deposit chemistry," Corrosion Science, vol. 44, no. 2, pp. 265-283, 2002.

[4] Y. Shinata and Y. Nishi, "NaCl-induced accelerated oxidation of chromium," Oxidation of Metals, vol. 26, no. 3-4, pp. 201$212,1986$.

[5] N. Hiramatsu, Y. Uematsu, T. Tanaka, and M. Kinugasa, "Effects of alloying elements on $\mathrm{NaCl}$-induced hot corrosion of stainless steels," Materials Science and Engineering A, vol. 120-121, no. 1, pp. 319-328, 1989.

[6] Y. S. Li, M. Sanchez-Pasten, and M. Spiegel, "High temperature interaction of pure Cr with $\mathrm{KCl}$," Materials Science Forum, vol. 461-464, pp. 1047-1054, 2004.

[7] F. Wang and Y. Shu, "Influence of Cr content on the corrosion of $\mathrm{Fe}-\mathrm{Cr}$ alloys: the synergistic effect of $\mathrm{NaCl}$ and water vapor," Oxidation of Metals, vol. 59, no. 3-4, pp. 201-214, 2003.

[8] C. J. Wang and Y. C. Chang, "NaCl-induced hot corrosion of Fe-Mn-Al-C alloys," Materials Chemistry and Physics, vol. 76, no. 2, pp. 151-161, 2002.

[9] Y. S. Li, Y. Niu, and W. T. Wu, "Accelerated corrosion of pure $\mathrm{Fe}, \mathrm{Ni}, \mathrm{Cr}$ and several Fe-based alloys induced by $\mathrm{ZnCl}_{2}-\mathrm{KCl}$ at $450^{\circ} \mathrm{C}$ in oxidizing environment," Materials Science and Engineering A, vol. 345, no. 3, pp. 964-970, 2003.

[10] F. H. Stott and G. C. Wood, "Internal oxidation," Materials Science and Technology, vol. 4, no. 12, pp. 1072-1078, 1988.

[11] G. Han and W. D. Cho, "High-temperature corrosion of $\mathrm{Fe}_{3} \mathrm{Al}$ in $1 \% \mathrm{Cl}_{2} \mathrm{Ar}$," Oxidation of Metals, vol. 58 , no. 3-4, pp. 391$413,2002$.

[12] F. Lang and $\mathrm{Z}$. Yu, "Corrosion behavior of $\mathrm{Fe}-40 \mathrm{Al}$ sheet in $\mathrm{N}_{2}-11.2 \mathrm{O}_{2}-7.5 \mathrm{CO}_{2}$ atmospheres with various $\mathrm{SO}_{2}$ contents at 1273 K," Intermetallics, vol. 11, no. 2, pp. 135-141, 2003.

[13] Y. Kawahara, "High temperature corrosion mechanisms and effect of alloying elements for materials used in waste incineration environment," Corrosion Science, vol. 44, no. 2, pp. 223232, 2002.

[14] U. Ducati, G. L. Coccia, and G. Caironi, "Electrochemical evaluation of hot corrosion resistance of metallic materials," Materials Chemistry and Physics, vol. 8, no. 2, pp. 135-145, 1983.
[15] C. L. Zeng, P. Y. Guo, and W. T. Wu, "Electrochemical impedance spectra for the corrosion of two-phase $\mathrm{Cu}-15 \mathrm{Al}$ alloy in eutectic $(\mathrm{Li}, \mathrm{K})_{2} \mathrm{CO}_{3}$ at $650^{\circ} \mathrm{C}$ in air," Electrochimica Acta, vol. 49, no. 9-10, pp. 1445-1450, 2004.

[16] C. L. Zeng, W. Wang, and W. T. Wu, "Electrochemical impedance models for molten salt corrosion," Corrosion Science, vol. 43, no. 4, pp. 787-801, 2001.

[17] K. Shirvani, M. Saremi, A. Nishikata, and T. Tsuru, "Electrochemical study on hot corrosion of Si-modified aluminide coated In-738LC in $\mathrm{Na}_{2} \mathrm{SO}_{4}-20$ wt. $\% \mathrm{NaCl}$ melt at $750^{\circ} \mathrm{C}$," Corrosion Science, vol. 45, no. 5, pp. 1011-1021, 2003.

[18] B. Zhu, G. Lindbergh, and D. Simonsson, "Electrochemical impedance studies of the initial-stage corrosion of $310 \mathrm{~S}$ stainless steel beneath thin film of molten $(0.62 \mathrm{Li}, 0.38 \mathrm{~K})_{2} \mathrm{CO}_{3}$ at $650^{\circ}$ C," Corrosion Science, vol. 41, no. 9, pp. 1497-1513, 1999.

[19] C. Cuevas-Arteaga, J. Uruchurtu-Chavarín, J. Porcayo-Calderon, G. Izquierdo-Montalvo, and J. Gonzalez, "Study of molten salt corrosion of $\mathrm{HK}-40 \mathrm{~m}$ alloy applying linear polarization resistance. And conventional weight loss techniques," Corrosion Science, vol. 46, no. 11, pp. 2663-2679, 2004.

[20] C. Cuevas-Arteaga, J. Uruchurtu-Chavarín, J. G. González, G. Izquierdo-Montalvo, J. Porcayo-Calderón, and U. Cano, "Corrosion evaluation of Alloy 800 in sulfate/vanadate molten salts," Corrosion, vol. 60, no. 4, pp. 520-527, 2004.

[21] C. Cuevas-Arteaga, "Corrosion study of HK-40 m alloy exposed to molten sulfate/vanadate mixtures using the electrochemical noise technique," Corrosion Science, vol. 50, no. 3, pp. 650-663, 2008.

[22] J. G. Gonzalez-Rodriguez, O. L. Arenas, J. Porcayo-Calderon, V. M. Salinas-Bravo, M. Casales, and A. Martinez-Villafañe, "An electrochemical study of the effect of B on the corrosion of atomized Fe40Al intermetallics in molten $\mathrm{Na}_{2} \mathrm{SO}_{4}$," High Temperature Materials and Processes, vol. 25, no. 2, pp. 293301, 2006. 

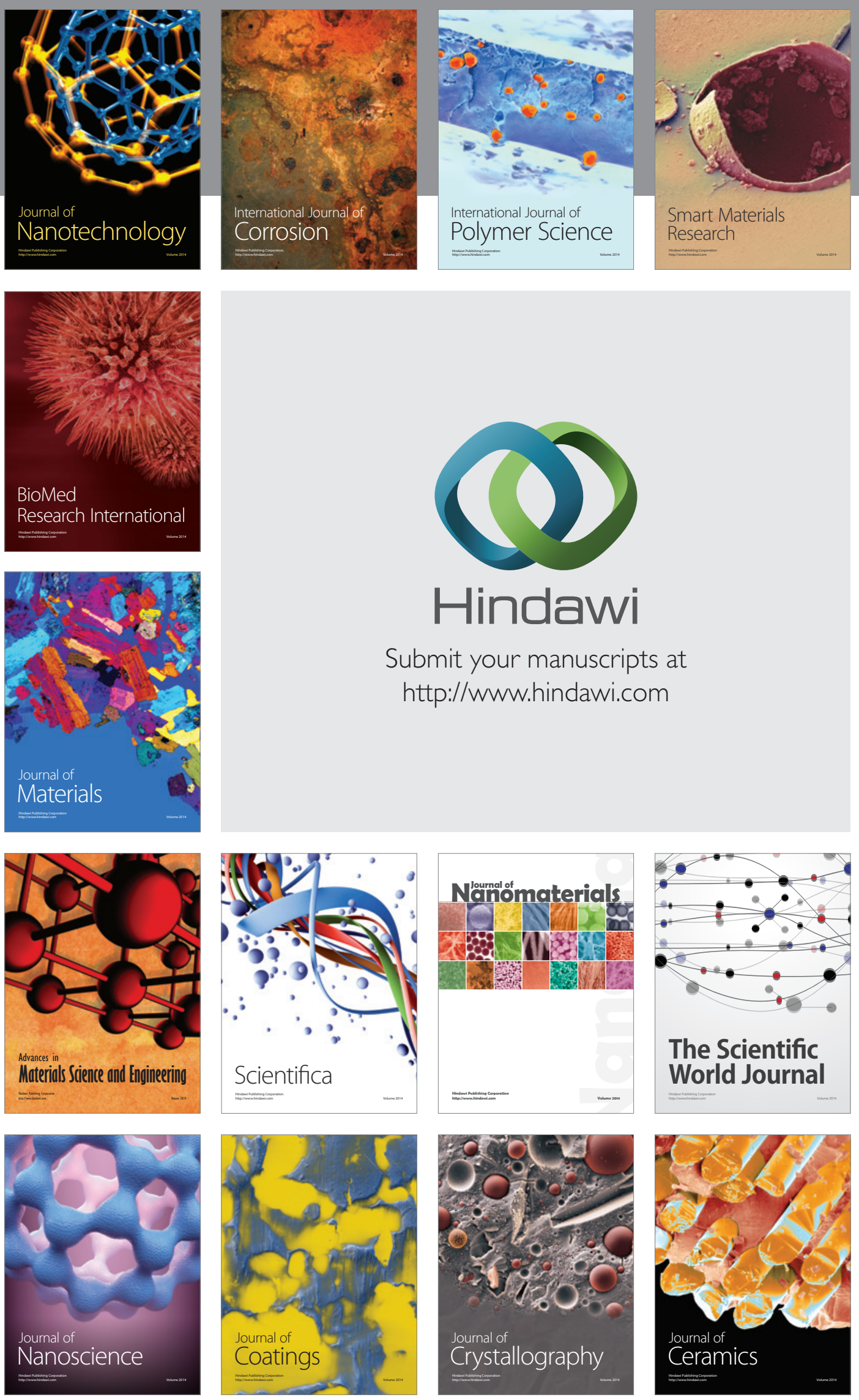

The Scientific World Journal

Submit your manuscripts at

http://www.hindawi.com

\section{World Journal}

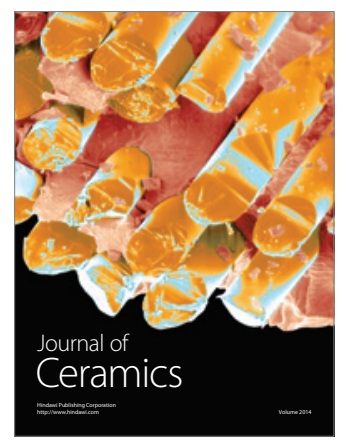

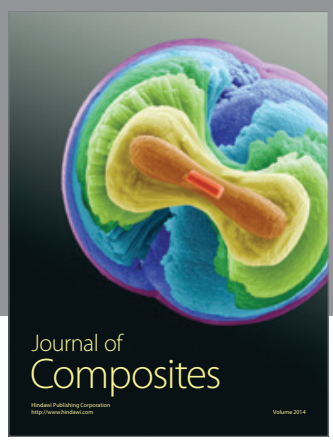
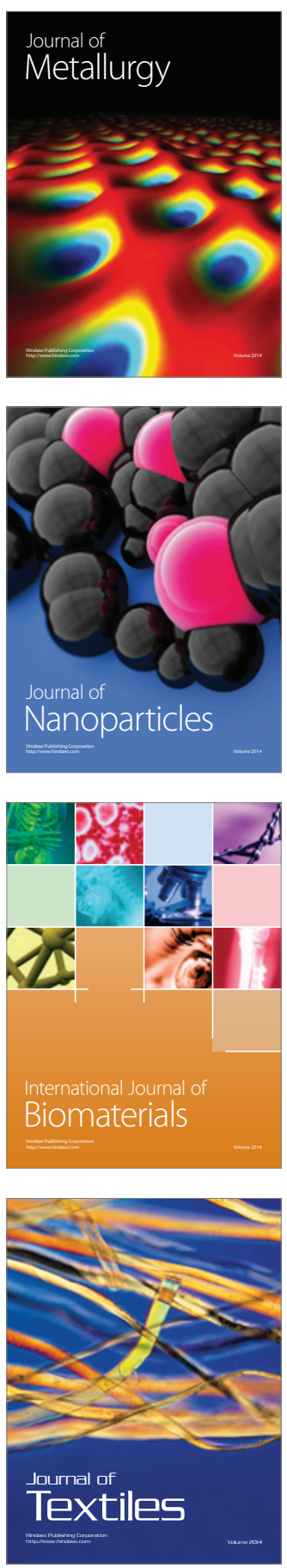